\title{
BRINGING CLINICAL LEARNING INTO A CONVENTIONAL CLASSROOM
}

\author{
KATHY MACK*
}

Some forms of clinical legal education have been part of Australian legal education for many years. However, the focus of this clinical legal education has tended to emphasize either practice-oriented skills training, such as in the post graduate legal practice courses, or client service, which is emphasised at the Kingsford Legal Clinic, the Monash/Springvale program and the proposed Queensland program. ${ }^{1}$

Although attention to clinical legal education has increased recently among university based law schools in Australia, ${ }^{2}$ there is still some of the unfortunate polarization of views which marked the early days of the US debate about clinical legal education ${ }^{3}$ Conventional law teachers criticize clinical legal education for being limited to narrow, vocationally directed skills training, lacking rigour and a sufficient theoretical perspective, while clinicians accuse conventional academic legal education of being too theoretical or abstract, limited to narrow doctrinal concerns and unrelated to the real legal world. ${ }^{4}$

This essay attempts to overcome this polarization by exploring clinical legal education in a broader sense, emphasizing ways in which clinical methods and insights can be integrated into existing university legal education and describing benefits to be derived from such integration. Incorporating clinical legal education into Australian legal education can improve student learning of conventional legal doctrine and analysis by putting the limited materials used in legal education (appellate cases and statutes) into their dynamic context ${ }^{5}$ and by making students more active participants in their own learning. ${ }^{6}$ Including some elements of 
clinical legal education also strengthens conventional legal education by broadening it. Lawyering activities and the legal process outside of appellate decisions and statutes become subjects for teaching and academic, intellectual inquiry. ${ }^{7}$ Students gain additional insight into the professional and ethical obligations of lawyers ${ }^{8}$ and, perhaps most importantly, learn to self-evaluate and to learn from their own experience. ${ }^{9}$

It is best to begin by asking what is meant by "clinical legal education", since the phrase is applied to such a wide range of educational goals, methods and substantive topics that clear discussion can sometimes be difficult. ${ }^{10}$ Rather than reiterating the skills vs theory debate, it is important to focus on commonality and clarity in discussions about the nature and future of clinical legal education in Australia.

What is special or distinctive about clinical legal education? The two main distinguishing features of clinical legal education are first, the method of teaching and learning used and second, the aspects of law and the legal system which can be studied using this method. Though there are clearly important connections between the methods of clinical legal education and the subjects being examined, it is worth discussing each aspect separately. ${ }^{11}$

As a method of teaching and learning, the distinctive element of clinical legal education is its emphasis on structured student experience and thoughtful feedback on that experience as the core of learning. Clinical method combines

student performance of a lawyering task and feedback. Instead of asking a student what [evidentiary] objection might be made, the clinical method requires the student to make the objection. Instead of asking what foundation is required to admit an item of evidence, the clinical method requires the student to lay the foundation by calling the necessary witness ... and then asking the necessary questions. This method requires the student to learn by doing. ${ }^{12}$

A more elaborate description of the essential elements of clinical legal education is that developed by Anthony Amsterdam:

1. Students were confronted with problem situations of the sort that lawyers encounter in practice. The situations might be simulated ... or they might be real ...

2. The problem situations were: (a) concrete, that is, textured by specific factual detail; (b) complex, that is, they required the consideration of interacting factors in a number of 
dimensions-legal, practical, institutional, personal; and (c) unrefined, that is, they were not predigested for the student through the medium of appellate opinions or coursebooks, but were unstructured, requiring the student to identify "the problem[s]" or "the issue[s]".

3. The students dealt with the problem in role [emphasis in original]. They bore the responsibility for decision and action to solve the problem. They had to: (a) identify the problem; (b) analyze it; (c) consider, formulate and evaluate possible responses to it; (d) plan a course of action; and (e) execute that course of action. In all of these activities, the students were required to interact with other people ...

4. The students' performance was subjected to intensive and rigorous post mortem critical review. With faculty and other students, the performing students sat down, recreated and criticized every step of their planning, decision-making and action. Sometimes this was done by replaying videotapes or audiotapes of their performance, sometimes by reviewing notes and memoranda ...

5. This critical review focused upon the development of models of analysis for understanding past experience and for predicting and planning future conduct. It identified and explored the questions to be asked following any experience ... in order to draw from that experience the maximum of learning it can provide. ${ }^{13}$

The "problem situation" or "lawyering task" may be created by a simulation of lawyer roles and activities or it may be actual work experience in lawyer roles, either through a law office run by the law school or by supervised placement with an external office. Simulation and direct client service methods are not mutually exclusive. Often particular subjects are taught using some combination of clinical methods with more conventional methods, such as lecture, tutorial, seminar or socratic teaching.

Clinical legal education in the form of work experience can vary from brief participant observation in a court, law office, administrative agency or government office, to actual client representation at trial or appellate level, for a full semester or longer, working full time or part time. ${ }^{14}$

Simulated clinical legal education can be very brief, an occasional 
adjunct to a conventional course or very elaborate, implemented by detailed stimulus materials to set up roles and tasks, accompanied by background reading and consisting of several phases including planning, performance (which may include writing), critique, (by self, instructor, and peers) followed by reflection and synthesis. ${ }^{15}$

Other teaching methods sometimes discussed as part of clinical legal education are the problem $\operatorname{method}^{16}$ and simulation and gaming. ${ }^{17}$

The problem method is not as a elaborate as a full clinical program but shares with clinical legal education an emphasis on learning by doing and the open-textured undigested presentation of the problem. Nathanson identifies several essential features of problem solving including problem identification, fact investigation, legal issue identification and assessment, developing options, evaluating options, choosing options and planning and implementing options. ${ }^{18}$

Nathanson specifically distinguishes the elaborate problem method assignment from "undergraduate law exercises, in which the primary objectives are to test a student's ability to recognize and articulate legal issues in a [given] fact pattern and to give a reasoned opinion about which party would succeed should the facts be placed before a judge." ${ }^{19}$ In the problem method of teaching, the problem is a vehicle for learning, not assessment. The situation or problem is given first, usually in detailed written form. Students must learn/select what is needed to solve the problem, using materials (factual and/or legal) included with the problem or which they find through their own research. The students apply what they have learned to the problem. The results of this learning are then presented back to the class and/or the instructor, in writing or through discussion. ${ }^{20}$

Simulation and gaming, in the context of legal education, are less rigid and formal versions of role playing exercises, ${ }^{21}$ and both differ from formal clinical legal education as defined above in that they do not necessarily involve students in a lawyer role. Within a conventional law course, limited simulations can be used to "illustrate a problem for class discussion, to teach substantive law, to develop students' skills in investigating, reasoning, negotiating or arguing, and planning, or to confront students with the realities of an ethical dilemma”. ${ }^{22}$

A particularly vivid example of a simulation in a law school 
class where students do not act in lawyer role is described by McAninch. The issue to be addressed in a class on constitutional law was a line of US Supreme court cases attempting to determine what, if any, prayer in school was permissible in light of the First Amendment. Some of the early cases focused on whether the prayer was voluntary or compulsory. McAninch began his class that day by announcing that he would lead the class in prayer, and that all who were uncomfortable with this could leave. He then recited a brief statement of praise to Allah. The class discussed their own reactions to this event, greatly clarifying their insights into voluntary and compelled behavior. ${ }^{23}$

The key features of all forms of clinical legal education are experience and feedback, what Amsterdam calls the roleplay and the critical functions. The term some commentators prefer to use is experiential legal education, because it focuses on the essential idea of learning by doing, and broadens the frame of discussion, whereas the phrase clinical legal education may narrow or polarize. In the discussion that follows, the term clinical legal education will be used in its broadest sense, as a method of teaching and learning and as a way to make the legal process and lawyering activities (beyond appellate decisions and statutes) a subject of intellectual inquiry.

Usually, when clinical legal education is mentioned, a focus on lawyer tasks comes to mind. These are the topics which tend to be most closely associated with a limited view of clinical legal education as skills training. However, law school classes using clinical methods may also examine some aspect of the legal process, such as injunctions or dispute resolution, or virtually any and all other areas of substantive or adjectival law. One of the great strengths of clinical legal education is to help us understand the unbreakable nexus between substantive law, legal process and lawyer tasks, ${ }^{24}$ and between theory and practice. ${ }^{25}$

For example, it is often assumed that the reason to have a subject on legal interviewing is to teach students the skills of interviewing and how to conduct an interview with a client or witness. However, it is not necessary to take such a limited view of a lawyering task subject. Certainly, skills training is one goal which such a class could have, and it is perhaps the main goal of such classes in the post graduate legal practice programs. However, a 
course in legal interviewing in a university law school would have a much broader and more theoretical direction. Such a subject would facilitate the academic examination of the lawyering process itself, which is an essential part of law and the legal system.

We accept that statutes and appellate opinions are worthy of academic study. As argued by the Legal Realists beginning in the $1930 s,{ }^{26}$ a full study of law must include studying what lawyers do and the interaction between lawyers and lawyers, lawyers and clients and lawyers and judges, since "the law", or the doctrines of the law, do not exist outside of the dynamic context in which the law is created, used and applied. ${ }^{27}$ Through clinical education, we now have techniques to study law in a more complete way. ${ }^{28}$

Clinical legal education has led to a "systematic scrutiny of all aspects of the lawyering role and function-no matter how small or large a slice of the lawyering process is to be examined". ${ }^{29}$ For example, Galanter uses a class in negotiation "as a platform for intellectual reorganization of the law school experience”. In his view, settlement is the core of legal process; law is one counter in the negotiation, and justice can be present or absent in formal legal processes as well as in bargaining. He uses readings, simulations, films and visitors to explore these ideas. ${ }^{30}$

A somewhat different aspect of a clinical program is to "provide a laboratory in which students and faculty study, in depth, particular substantive areas of the law." ${ }^{31}$ For example, substantive topics which have been taught at one leading US law school using clinical methods include education law, business planning, poverty law, juvenile law, privacy, freedom of information, real estate transactions, evidence, family law, entertainment industry transactions, estate planning and immigration law. ${ }^{32}$ Legal journals, especially the Journal of Legal Education, frequently include descriptions of conventional law subjects taught by various clinical methods. Examples include administrative law, ${ }^{33}$ constitutional law, ${ }^{34}$ bankruptcy, ${ }^{35}$ contract, ${ }^{36}$ business law, ${ }^{37}$ torts, ${ }^{38}$ evidence, ${ }^{39}$ legislation, ${ }^{40}$ property, ${ }^{41}$ conflicts of laws, ${ }^{42}$ criminal law. ${ }^{43}$

Through clinical legal education, the necessary interaction between looking at lawyers, understanding legal process and examining substantive law and doctrine becomes much clearer. Just as the Legal Realists pointed out that understanding substantive law requires an understanding of the legal process and of lawyering, the 
converse is equally true: "Any inquiry into what lawyers do must necessarily consider what the legal system permits, demands, requires and provides."44

What does clinical legal education do that is more important or different or better than conventional legal education? To the extent that its goals are similar to those of conventional legal education, why, according to proponents of clinical legal education, is clinical legal education preferable? Why should any of these methods be used in addition to or in preference to conventional methods? What problems are associated with clinical legal education?

In order to understand and evaluate the opportunities presented by clinical legal education, it is first necessary to have some understanding of the goals of legal education as presently expressed in Australia. The Pearce report for CTEC, although not universally praised and accepted, provides a comprehensive consideration of the goals of legal education in Australia today. According to this report, the essential goals of legal education include:

- core knowledge of the law, ... key aspects of the legal system and legal institutions, legal processes and method and basic areas of legal principle. ${ }^{45}$

- intellectual skills of reasoning, analysis, critical thought and enquiry and skills at research and at bringing to bear theory, policy and information on the solution of problems. ${ }^{46}$

- training of students for the legal profession and for other careers involving legal work. ${ }^{47}$

The report further points out that “... a principal service to a law student may well be to equip that person with the skills necessary to acquire ... knowledge"48

What are the goals of clinical legal education, and how do they compare to conventional legal education? In its earliest development, clinical legal education goals were fairly limited. The major purposes were "training law students in lawyering skills, introducing students to the full scope of the legal system and its actors, [and] developing in students an understanding and appreciation of professional responsibility". ${ }^{49}$ Proponents of clinical legal education emphasized "the ability to offer new areas of substantive learning ... not taught in the traditional law school curriculum". 50

These goals are still important aspects of some clinical legal 
education programs, but clinical legal education is no longer limited to these goals. "Clinical education is not simply a substitute for the first year of practice, nor is it an escape from the 'rigors' of intellectual pursuit, nor is it just a process of teaching 'how to' and practical skills." ${ }^{\text {1 }}$ The goals of clinical legal education when articulated in the context of a university based academic law program include many of the same goals as traditional legal education, sometimes with different emphasis, as well as some goals specific to particular forms of clinical legal education..

At Boalt Hall, the law school of the University of California, Berkeley, the goals of the clinical subjects include a "broader understanding of the legal process, enhanced learning of substantive law and more effective participation in conventional law school classes". ${ }^{52}$ At the University of New Mexico, clinical methods and materials are integrated into the Evidence course, with the stated goals that "students should learn the doctrines of evidence law and they should gain some appreciation for the practical application of evidence rules". ${ }^{53}$ The goals of a clinical criminal law course include teaching students to identify facts and applicable law and to predict outcomes, to organize and present arguments of law and fact, to acquire or increase knowledge of substantive criminal law and to integrate criminal law, criminal procedure, evidence and other doctrines. ${ }^{54}$ The goals of the proposed Queensland client service clinical program include enhancing education by showing law in action, improving skills of fact gathering and analysis, developing professional responsibility and providing community service.

The purposes described for these programs have much in common with what some hope to do through traditional legal education in Australia. The emphasis on understanding substantive law, legal doctrine and the legal process are essential features of conventional and clinical legal education, as is a focus on teaching students that distinctive yet ephemeral quality of legal reasoning or "thinking like a lawyer".

Many of the benefits of clinical legal education relate to integration of different areas of law, ${ }^{55}$ integration of law and fact, ${ }^{56}$ synthesis of legal and non-legal materials ${ }^{57}$ and improved problem solving skills, such as issue recognition, planning, strategy, tactics, analysis, synthesis, and decision making. ${ }^{58}$ These are the sorts of 
"generic" skills which legal education must foster, since legal knowledge rapidly becomes outdated. ${ }^{59}$

Experiential teaching and the feedback which is an essential part of it

enhance rather than detract from our traditional concern for rigorous analytical training. Experiential exercises give the teacher new access to students' thought processes. Skilful feedback and reflection explore such questions as what assumptions of law, fact, and value were made by the student role player; how the framing of a question influences the answer; how legal reasoning distinguishes essentials from tangentials ${ }^{59}$ and irrelevancies; and why it is important to examine alternatives before reaching a conclusion. ${ }^{60}$

The analogy emphasized is "like requiring math students to show their work as well as their answers.”61

Traditional legal education is sometimes criticized for inadequate attention to the significance of facts in legal analysis. ${ }^{62}$ Most teachers are familiar with the "problem of the bright student who has been trained to deal with doctrine and principles in a tight and logical manner. However, when he or she approaches a problem where he or she must select and analyze the important facts and determine the relevant doctrine, he or she has a great deal of difficulty." ${ }^{63}$ Because clinical legal education presents facts in "undigested form, it leads to improved understanding of the interaction of law and fact. The "problem of finding and marshalling facts is quite different from following a court through its analysis of facts already marshalled.”64

Perhaps the most important benefits of clinical legal education are in areas not usually regarded as central to legal education (indeed, they are topics which conventional law teaching addresses rarely if at all) but they can complement all forms of education, including traditional legal education. These benefits include improved interpersonal skills, ${ }^{65}$ a high degree of motivation and enthusiasm, ${ }^{66}$ and a higher standard of work, because the consequences of poor work are immediate and inescapable. ${ }^{67}$ Most important is that clinical legal education makes students more active participants in their own education. ${ }^{68}$

More than ten years ago, Lücke criticised Australian legal education for requiring too much listening and not enough doing. ${ }^{69}$ Clinical legal education changes the focus from passive listening to action. "Experience based learning is dramatically different from 
traditional classroom learning ... it is much more self-oriented and directed."70 "Simulations can transform students from passive, detached observers into involved participants in the learning process". ${ }^{71}$ For example, in a US constitutional law class, where the students were organized into groups, each "role playing" the views of a single judge over a series of Supreme court cases, the instructor concluded that the students had an enhanced understanding of constitutional themes, policies, arguments and doctrines, the role of facts in constitutional disputes, that students were less bored and benefited from working in groups. ${ }^{72}$

In addition to using clinical legal education to better achieve goals shared with traditional legal education, clinical programs can expand the intellectual and pedagogic mission of legal education. Using experiential methods to examine law in its professional and social context creates a special opportunity for students and teachers to more fully understand $\operatorname{law}^{73}$ and to develop theories about law. ${ }^{74}$ Clinical methods are uniquely appropriate for teaching professional responsibility ${ }^{75}$ and the ability to self evaluate and to learn from one's own experience. ${ }^{76}$

Extending Australian academic legal education to include these goals would not be inconsistent with conventional legal education and, indeed, would enhance it. ${ }^{77}$ Several commentators have expressed concern about excessive "rule orientation" and formalism in Australian legal education, observing that the narrow doctrinal focus which too often dominates Australian legal education is neither theory nor practice. ${ }^{78}$ Integrating some forms of clinical legal education, with its greater attention to law in context and the actual functioning of legal institutions will broaden the scope of academic inquiry and help reduce this narrow rule focus.

Clinical legal education “... enables students to understand problems in their true context rather than as isolated disconnected episodes."79 Even a relatively limited role as a participant observer in a significant legal institution such as a court, law firm, legal aid office, Attorney-General's department or administrative agency can give significant "systems operation knowledge" which is not accessible through conventional legal education. ${ }^{80}$ Their real world experience, especially of the legal process, enhances students' understanding of conventionally taught subjects. ${ }^{81}$

... experiential exercises can teach lessons about process and role that 
are difficult to appreciate in more abstract discussions of appellate cases: the difficulty of ascertaining what the facts are; the critical role played by personal interaction between lawyers and witnesses in developing a factual record; the uncertainties and ambiguities faced by a lawyer seeking to advise a client on the 'law' applicable ... the effects of proposed reforms on the conduct of lawyers; the actual impact of litigated solutions on clients' lives; the way problem solving can transform win-lose competition into win-win cooperation; the degree to which understandings of substantive law affect conduct and transactions that are never scrutinized by a court or administrative agency; how painful resolving conflicting duties to court, client and self can be; the difficulty of making one's ideals and theories about law consistent with actual practice. ${ }^{82}$

As well as enhancing student understanding of substantive law by putting it into context, examined experience in clinical legal education gives a unique opportunity for empirical research and scholarship $^{83}$ and "affords students of the legal system a unique opportunity to study the law, observe its application in action and examine its impact ... ${ }^{84}$ Student clinical experience also enriches the faculty by bringing to their attention new and untapped areas of legal research. ${ }^{85}$ This theoretical component of clinical legal education has been successfully pursued in many contexts. ${ }^{86}$ For example, one academic writer engaged in clinical legal education has developed several distinct theories or models of lawyering. ${ }^{87}$ There is now a fairly extensive scholarly literature articulating theories about the lawyer-client relationship derived from clinical legal education programs on interviewing. ${ }^{88}$

A greater emphasis on professional responsibility is also an appropriate component of academic undergraduate legal education. Since the main path to legal practice in Australia is usually university based legal education, ${ }^{89}$ we must recognize that although not all of our students become legal practitioners, virtually all lawyers were once our students. What they did (or did not) learn in law school has tremendous impact on the legal profession and the community it serves. Our curriculum and our teaching methods must recognize that, as pointed out in the Pearce report, "training of students for the legal profession and for other careers involving legal work" ${ }^{90}$ is necessarily one of the functions of even the most theoretically oriented law schools in Australia.

We must further acknowledge that whether or not we explicitly address professional responsibility in our classes, we cannot avoid teaching something about legal ethics and moral choices. ${ }^{91}$ If we 
say nothing, we are giving the message that it is unimportant or implicitly reinforcing whatever image the students have of lawyers and legal ethics. When we discuss legal decision-makers and when we teach doctrine through cases and hypotheticals, we create images of law and lawyers which have ethical components. ${ }^{92}$

Teaching professional responsibility is an area in which the benefits of clinical education seem to be most impressive. ${ }^{3}$ Direct client service clinics can increase student awareness of the legal problems of the poor, teach social responsibility to future members of the legal profession, ${ }^{94}$ and provide needed service to the community. ${ }^{95}$ Client service in legal aid clinics gives law students, who are often from middle class or upper middle class backgrounds, a greater understanding of the reality of social disadvantage and may create a sense of professional obligation of service to the disadvantaged. ${ }^{96}$

Professional responsibility can also be effectively taught in simulated clinical programs. One example which Amsterdam often uses involves a simulated exercise in which students were interviewing a witness prior to testimony. After giving information favorable to the students' side, the witness asked how much he would be paid. The students, who had previously read and discussed the relevant canons of ethics, were unable to come up with a clear, decisive response, making vague noises about expenses, and obviously became more uncomfortable as the witness's memory became less helpful. The intensity of the simulated circumstances presented the ethical problem and the difficulties of coming up with a proper solution more vividly than any lecture or seminar. ${ }^{97}$

Perhaps the most important benefit of clinical legal educations is its ability to teach students how to teach themselves and to learn from their own professional and personal experience. ${ }^{98}$

The value of experiential exercises, however, goes far beyond their suitability for teaching creative problem solving ... Perhaps the most powerful potential of experiential learning is that it can teach students a method of evaluating their own experience that will allow them to continue to learn after they leave law school..$^{99}$

The questions students learn to ask themselves about their own experiences "are the beginning of the students' development of conscious, rigorous self-evaluative methodologies for learning from 
experience-the kind of learning that makes law school the beginning, not the end of ... legal education."100

"Any educational process must produce self-learning skills in its students. Students must learn a method of learning independently that will enable them to solve problems they will confront outside the educational environment." 101 This is especially true of legal education. Producing students who are active learners responsible for their own education who can continue to educate themselves must be the goal of all law schools, since what we do in the university can only be the beginning and not the completion of legal education. ${ }^{102}$ As the president of the AALS stated, the "aim of the law school is not to train lawyers, but to educate [individuals] for becoming lawyers." 103

Why/how does clinical legal education achieve these results? As described above, the essential elements of clinical legal education (and experiential education generally) are role play and feedback. An expanded description of the stages of experiential learning includes participation, reflection, formulation of an abstract generalization which synthesizes significant aspects of the experience, and testing the generalizations. ${ }^{104}$ The stages of reflection and especially generalization are essentially intellectual and quite similar to traditional legal education. 'What distinguishes experiential from traditional teaching is that the largely intellectual aspects of ... [reflection and generalization] are based on concrete experiences rather than intellectual constructs." 105 Sometimes, experiential learning is criticized for being gimmicky or merely attention grabbing entertainment without substance. It is obvious that "[1]earning does not result only from experience ..." must be emphasized is that the essential element of clinical legal education and all experiential learning are the two elements of role play (experience) and feedback (reflection). "[E]xperiential learning cannot live up to its potential unless it is accompanied by a process of carefully supervised evaluation and reflection."107 "The absence of direct feedback and reinforcement in traditional legal education is one of its weaknesses.” 108 “... [F]or most law students the only significant consequence in any course is the ... final examination."109 Educational psychology has long recognized that "feedback and reinforcement are essential to appropriate and meaningful learning." 110 
There is feedback in some elements of conventional legal education in Australia, for example, in good tutorials, where there is active participation by students. But this approach lacks the full impact of clinical legal education because it does not contain the experiential element. It is, as Romero pointed out, the difference between asking a student what an evidentiary objection might be and requiring the student to actually raise an objection to a particular question of a particular witness in a real or simulated trial. Both the experience and the feedback are essential components if clinical legal education is to have its full benefits.

Incorporating clinical goals, methods and insights into conventional programs will be an important step in the fuller education of all our students and will enhance the high intellectual and academic standards of university education. ${ }^{111}$

The benefits of clinical legal education are not guaranteed, however. Like any other teaching method or approach, clinical legal education can be done badly, either in the experience/ role play phase or the feedback/critique phase. It is, however, important to avoid comparing good clinical legal education with bad traditional legal education, or vice versa. Evaluation of clinical legal education will only be helpful if we are careful to compare ideal with ideal, real with real, and to identify what is actually being done, and what it is possible to do with clinical methods in the actual Australian situation. Any potential problems must be discussed specifically in relation to the particular clinical program being considered.

The activities undertaken by a student in an actual client service can be limited or inconsistent. There can be poor supervision in clinics, especially a risk where the supervision comes solely from busy practitioners rather than law school faculty. This is similar to the faults that led to the rejection of the articles year as a component of Australian legal education. ${ }^{112}$ Inadequate supervision means insufficient attention is being paid to the crucial feedback phase. ${ }^{113}$

Simulations can be badly designed, and the instructor's approach to the critiques or feedback can be so insensitive, controlling or didactic that most of the student-centered, selfteaching benefits can be lost. ${ }^{114}$

Elaborate forms of clinical legal education, with much 
videotaping and individual critique, can be expensive. ${ }^{115}$ They can be very labor intensive, ${ }^{116}$ causing high staff costs. There may be costs to providing special facilities not usually part of a conventional academic law school, such as actual or simulated law offices or facilities for video taping and viewing simulations.

Some commentators have argued that clinical legal education's promise of greater theoretical development has not been realized, while others argue for a broader concept of scholarship and theory to reflect the real contributions of clinical legal academics. ${ }^{117}$

Clinical legal education can be a challenge for teachers, offering opportunities as well as obstacles. ${ }^{118}$ Specialists in clinical education can be marginalized, with lower pay and status, or their contributions may be seen as less worthwhile than conventional teaching or research. ${ }^{119}$ Some of the more elaborate forms of clinical teaching do require some skills which are not always found among conventional teachers. ${ }^{120}$ Greater attention to interpersonal skills, ${ }^{121}$ especially in the critique/feedback stage, is essential. This greater emphasis on the personal can lead to instructor "burnout." "122 Conventional exam based assessment methods are inappropriate for most clinical legal education programs. ${ }^{123}$ Encouraging the self-directed learning of clinical legal education necessarily moves the instructor away from center stage ${ }^{124}$ and requires us to view our students as individuals. ${ }^{125}$ Some teachers, used to the captive audience of the lecture format, may find this a difficult adjustment.

Overall, the educational obligations on the law teacher who wishes to use clinical methods are not essentially different to the demands on a conventional law teacher, especially when looking at an integration of some clinical method and inquiry into a conventional program.

The law teacher's responsibility is to ... select the specific educational goals ... and construct the total and specific educational package that is best adapted to attaining the selected goals. This process will necessarily include: (1) analysis of the educational goals (2) selection of subject matter to be used as the focus of instruction (3) selection of the kinds of cases ... that will best lend themselves to attainment of the selected goals (4) determination of the teaching techniques to be used ... (5) determination of the mix of methods, if any, that would facilitate reaching the educational goals (6) selection of supplemental materials to be used ... ${ }^{126}$

Clinical legal education methods and topics are part of a larger 
spectrum from which we choose elements to design and plan our teaching. Instructors need not choose or commit to only one method of teaching. Just as different methods of learning will suit different students, ${ }^{127}$ different methods of teaching will suit different instructors and different educational goals.

None of the potential disadvantages of clinical legal education are total barriers to incorporating clinical methods and topics into a traditional program. We can cut our coat to the cloth of the financial and human resources available. Teachers who wish to incorporate some clinical legal education methods or topics of inquiry should be supported. Curriculum committees can maintain standards just as they do in conventional programs.

There are many combinations of theory and practice which permit clinical legal education methods and insights to be incorporated into traditional legal education. For example, it is possible to have a legal process subject using simulated clinical methods where the goal is not skills development, but a critical intellectual examination of the adversary legal system, such as Galanter's. ${ }^{128}$ Alternatively, a course in criminal law, taught by participation in a client service in-house legal clinic, may have specific substantive goals combined with particular skills goals, such as interviewing. A course in contracts using clinical methods and insights could examine the impact of adversary legal process on the common law development of substantive contract doctrines. An area which is becoming increasingly popular for combining clinical method with conventional legal education is the development of courses which incorporate some attention to negotiation, mediation or other forms of dispute resolution. ${ }^{129}$

One writer has given several examples of ways to use clinical legal education to teach traditional legal doctrine:

Remedies problems in contract could be taught through a negotiation simulation ... landlord tenant issues through a simulated interviewing and counselling session with a client about to negotiate a lease or seeking advice on how to break a lease, and the intricacies of proximate-cause doctrine through giving students the Palsgraf transcript and asking them to argue a motion for directed verdict on both sides. ${ }^{130}$

This same writer has shown how clinical methods can be used within the constraints of conventional teaching methods:

There are a number of different ways that such simulations can be used in traditional large classrooms. Perhaps the most familiar is the 
"fishbowl" in which one student or set of students performs the simulation before the whole class, followed by feedback and reflection that use the role play as the focal point of discussions. Alternatively, all students can do the simulation during or outside class time and analyze the experience in class. Students can also complete brief written reports on their process and results that can then be presented to the class as a whole. The two methods can be combined by video taping one or more of the out-of-class simulations and then laying all or parts of a tape for the class to discuss. ${ }^{131}$

This summary is really only a starting point. The ways in which clinical and traditional goals and methods can be integrated are limited only by human imagination.

The experience with many forms of clinical legal education in academic, intellectually oriented law schools shows that clinical legal education offers distinctive features and benefits, as well as overlapping with and enhancing the goals and methods of conventional legal education, and that there are some special advantages to incorporating some forms of clinical legal education into a conventional legal education program.

We as teachers tend to take for granted that our students have had certain experiences, which, if not essential, certainly facilitate learning. One who has dealt with landlords, tenants, realtors or buyers or sellers of property has an interest in and an appreciation of property law which she would otherwise lack. One who has never written a check would lack the understanding of negotiable instruments that other members of the class would have at the outset. Yet it may well be that whatever the subject, many of the students are approaching some of the issues abstractly, in a vacuum. By structuring an experience or two for them, we may become much more effective teachers, whatever our usual methodology. ${ }^{132}$

If we have a broader understanding of the goals, methods and benefits of clinical legal education and experiential learning methods generally, we may be able to avoid or reduce polarization of legal education into narrowly focussed skills and narrowly focussed academic/intellectual streams and to improve teaching, learning and research in all aspects of legal education.

* Senior Lecturer in Law University of Adelaide (c) 1993 (1993) 4 Legal Educ Rev 89.

1 RAF Stewart, Legal Education (1977) 51 ALJ 470; G Nash, CLE in Australia - the Monash Experience (1979) XII Council on Legal Education for Professional Responsibility (CLEPR) Newsletter; A Chay, A Clinical Legal Education Program for Queensland? (1991) Queensland L Soc'y J 49; Journal of Professional Legal Education; N Gold, K Mackie and W Twining, Learning Lawyers' Skills (London: Butterworths, 1989); Manual for the Simulation of the Family Court of Australia 2nd ed (Canberra: AGPS 1987). 
2 Examples include the conference sponsored by Kingsford in October 1991 and other events mentioned in the announcement for that conference; the survey of clinical legal education conducted by Sydney University; the appointment of a faculty member to specialize in clinical education as part of the startup of the new law school at Flinders University; and the integration of skills components throughout the degree structure at Griffith University, Bond University, Wollongong University and New South Wales Institute of Technology.

WN Keyes, Approaches and Stumbling Blocks to Integration of Skills Training and the Traditional Methods of Teaching Law (1980) 29 Clev St L Rev 685; N Gold, Themes, Trends and Prospects in Professional Legal Education and Training: A Global View (1985) 3 J Prof Legal Educ 171.

4 This polarization reflects, in part, the vocational vs academic tension which underlies virtually all aspects of legal education. CJH Thomson, Objectives of Education (1978) 52 ALJ 83, 84; R Cranston, Law and Society: A Different Approach to Legal Education (1978) 5 Monash L Rev, 54 at 61; W Twining, Pericles and the Plumber (1967) 83 LQ Rev 396.

5 LC Anderson and CE Kirkwood, Teaching Civil Procedure with the Aid of Local Tort Litigation (1987) 37 J Legal Educ 215; P Brest, A First Year Course in the 'Lawyering Process' (1982) $32 \mathrm{~J}$ Legal Educ 344; E Burg, Clinic in the Classroom: A Step Toward Cooperation (1987) 37 J Legal Educ 232, 251; D Brown, D Neal, D Farrier \& D Weisbrot, Criminal Law (Sydney: Federation Press, 1990) 1-14.

See infra, text at notes 69-72.

See infra, text at notes 24-44; 73-90.

See infra, 89-97

See infra, text at 98-103.

10 JM Brown, Simulation Teaching; A Twenty-Second Semester Report (1984) 34 $J$ Legal Educ 638; G Bellow, On Teaching the Teachers: Some Preliminary Reflections on Clinical Education as Methodology in CLE for the Law Student (Papers for the (CLEPR) National Conference June 69,1973) at 375.

11 One of the most interesting insights generated by clinical legal education is the challenge to the method/substance dichotomy itself, since, as will be seen, the subject and the method of clinical legal education is the examination of experience. P Goldfarb, A Theory-Practice Spiral: The Ethics of Feminism and Clinical Legal Education (1991) 75 Minn L Rev 1599 at 1667-1669; M Spiegel, Theory and Practice in Legal Education: An Essay on Clinical Education (1987) 34 UCLA L Rev, 577; B Blaustone, 'Teaching Evidence: Storytelling in the Classroom” (1992) 41 Am UL Rev, 453, at note 1.

12 L Romero, Integration of Clinical Methods and Materials into an Evidence Course, distributed at Association of American Law Schools (AALS) Annual Meeting January 1989.

13 AG Amsterdam, Clinical Legal Education-A 21st Century Perspective (1984) $34 \mathrm{~J}$ Legal Educ 612 at 616-617.

14 LC Anderson and CE Kirkwood, Teaching Civil Procedure with the Aid of Local Tort Litigation (1987) 37 J Legal Educ 215; S Wizner and D Curtis, 'Here's What We Do': Some Notes About Clinical Legal Education (1980) 29 Clev St L Rev, 673; Symposium, Clinical Legal Education and the Legal Profession (1980) 29 Clev St L Rev 345 at 735-815.

15 AALS/ABA Report of the Committee on Guidelines far Clinical Legal Education (AALS/ABA, 1980) 8-9.

16 S Nathanson, The Role of Problem Solving in Legal Education (1989) $39 \mathrm{~J}$ Legal Educ 167; GL Ogden, The Problem Method in Legal Education (1984) 34 J Legal Educ 654.

17 JD Harbaugh, Simulation and Gaming in AALS/ABA, Report of the Committee on Guidelines on Clinical Legal Education (AALS/ABA, 1980). 

(1984) 8 Seton Hall Legis J 19

41 JP Tomain, Lawyering in First Year Property (1983) 33 J Legal Educ 111; JM

S Nathanson, supra note 16 at 168.

Id at 167.

Winser, "Toe in the Bathwater: Testing the Temperature with Problem- based Learning” (1989) 7 J Prof Legal Educ 1; Ogden, supra note 16.

JD Harbaugh, supra note 17 at 208-210.

PJ Spiegelman, Integrating Doctrine, Theory and Practice in the Law School Curriculum: The Logic of Jake's Ladder in the Context of Amy's Web (1988) $38 \mathrm{~J}$ Legal Educ 243 at 258.

WS McAninch, Experiential Learning in a Traditional Classroom (1986) $36 \mathrm{~J}$ Legal Educ 420 at 420.

Brown, supra note 5 at 1-14; L Grosberg, Introduction: Colloquium: Currents in Clinical Scholarship (1990) 35 NY Law Sch L Rev 1; Goldfarb, supra note 11 at 1653 .

Id. Goldfarb, at 16-17; L Grosberg, Introduction: Colloquium: Currents in Clinical Scholarship (1990) 35 NY Law Sch L Rev l; M Spiegel, Theory and Practice in Legal Education: An Essay on Clinical Education (1987) 34 UCLA L Rev 577.

J Frank, Courts on Trial (Princeton N.J: Princeton University Press, 1950); KN Llewellyn The Bramble Bush (New York: Oceana Publications, 1930).

J Frank, Why not a Clinical Lawyer-School? (1933) 81 U Pa L Rev 907.

TJ Anderson and RS Catz, Towards a Comprehensive Approach to Clinical Education: A Response to the New Reality (1981) 59 Wash ULQ 727. The proposal for a clinical legal education program in Queensland emphasizes this "law in action " aspect. Chay, supra note 1; M Tushnet, Scenes from the Metropolitan Underground: A Critical Perspective on the Status of Clinical Legal Education (1984) 52 Geo Wash L Rev, 272; Spiegel, supra note 25; C Condlin, 'Tastes Great, Less Filling': The Law School Clinic and Political Critique (1986) $36 \mathrm{~J}$ Legal Educ 45 at 47.

C Menkel-Meadow, The Legacy of Clinical Education: Theories About Lawyering (1980) 29 Clev St L Rev, 555 at 556.

M Galanter, Worlds of Deals: Using Negotiation to Teach About Legal Process (1984) 34 J Legal Educ 268 at 273.

S Wizner and D Curtis, 'Here's What We Do': Some Notes About Clinical Legal Education (1980) 29 Clev St L Rev 673 at 678.

List compiled by Michael Wald, Stanford Law School.

E Burg, Clinic in the Classroom: A Step Toward Cooperation (1987) 37 J Legal Educ 232; M Botein, Simulation and Role Playing in Administrative Law (1974) 26 J Legal Educ 234.

RP Davidow, Teaching Constitutional Law and Related Courses Through Problem-Solving and Role-Playing” (1984) 34 J Legal Educ 527; DS Day, Teaching Constitutional Law: Role Playing the Supreme Court (1986) $36 \mathrm{~J}$ Legal Educ 268; WS McAninch, supra note 23.

P Fry, Simulating Dynamics: Using Role Playing to Teach the Process of Bankruptcy Reorganization (1987) 37 J Legal Educ 253.

K Hegland, Fun and Games in the First Year: Contracts by Roleplay (1981) $31 \mathrm{~J}$ Legal Educ 534.

DR Herwitz, Teaching Skills in a Business Law Setting: A Course in Business Lawyering (1987) 37 J Legal Educ 261.

JW Little, Skills Training in the Torts Course (1981) 31 J Legal Educ 614.

L Romero, supra note 10.

PG Schrag, Teaching Legislative Process through an Intensive Simulation

19 
Brown, Simulation Teaching; A Twenty-Second Semester Report (1984) $34 \mathrm{~J}$ Legal Educ 638 (land development law).

GR Shreve, Bringing the Educational Reforms of the Cramton Report into the Case Method Classroom — Two Models (1981) 59 Wash ULQ 793.

43 HI Subin, Clinical Pedagogy: The Educational Program of the NYU School of Law Criminal Law Clinic in AALS/ABA, Report of the Committee on Guidelines for Clinical Legal Education (AALS/ABA, 1980) at 251; TJ Andrews, The North Carolina Sentencing Seminar: An Experiment in Controlled Clinical Legal Education (1977) 28 J Legal Educ 317. Menkel-Meadow, supra note 29 at 556.

D Pearce, E Campbell, and D Harding Australian Law Schools; A Discipline Assessment for the Commonwealth Tertiary Education Commission; Summary (Pearce Report) (Canberra: AGPS, 1986) at 27.

FS Bloch, The Andragogical Basis of Clinical Legal Education (1982) 35 Vand $L \operatorname{Rev} 321$ at 322.

50 Id.

51 R Bird, Symposium: Prefatory Remarks (1980) 29 Clev St L Rev 356 at 359 (footnotes omitted).

52 School of Law, Boalt Hall, University of California, Berkeley, 1990- 91 Announcements, 9.

53 Romero, supra note 12.

54 I Subin, Clinical Pedagogy: The Educational Program of the NYLJ School of Law Criminal Law Clinic in AALS/ABA, Report of the Committee on Guidelines for Clinical Legal Education (AALS/ABA, 1980) at 25-258.

DR Herwitz, Teaching Skills in a Business Law Setting: A Course in Business Lawyering (1987) 37 J Legal Educ 261; Subin, id at 255.

56 Anderson \& Catz, supra note 28 at 739; R Bud, Symposium: Prefatory Remarks (1980) 29 Clev St L Rev 356 at 359; Brest, supra note 5 at 346; Seymour, CLEPR from the Viewpoint of the Practicing Bar, in CLE for the Law Student; Papers for the CLEPR National Conference June 6-9, 1973 (CLEPR, 1973) at 12; FW Munger, Clinical Legal Education: The Case Against Separatism (1980) 29 Clev St L Rev 715 at 725-6; Wizner \& D Curtis, supra note 14 at 677. Ogden, supra note 16 at 663.

58 Bellow, supra note 10; Ogden, supra note 16.

59 Nathanson, supra note 16.

60 Spiegelman, supra note 22 at 259-60.

61 Id at 260.

62 G Sokolow, From Kurosawa to (Duncan) Kennedy: The Lessons of Rashomon for Current Legal Education (1991) Wis L Rev 969 at 969- 970.

63 Bird, supra note 51 at 359.

64 Seymour, supra note 56 at 12.

65 W Pincus, Clinical Legal Education in the United States 1968-1975 (1975) 49 ALJ 420; Ogden, supra note 16. The lack of attention to personal skills in Australian legal education has been noted critically by G Nash, Skills Course or Clinic? (1980)54 ALJ 535 at 535.

66 Spiegelman, supra note 22 at 259; E Burg, Clinic in the Classroom: A Step Toward Cooperation (1987) 37 J Legal Educ 232 at 237 and 251.

67 Amsterdam, supra note 13.

68 Spiegelman, supra note 22 at 259. 
G Bellow and B

G Bellow and B Moulton, The Lawyering Process (New York: Foundation
Press, 1981); P Brest, A First Year Course in the 'Lawyering Process' (1982) 32

Stewart, supra note 1 at 472 quoting Horst Lücke.

DR Vetri, Educating the Lawyer: Clinical Experience as an Integral Part of Legal Education (1970) 50 Oregon LR 57, reprinted in CLEPR, Selected Readings in Clinical Legal Education at 206-7.

Spiegelman, supra note 22 at 259.

RP Davidow, Teaching Constitutional Law and Related Courses Through Problem-Solving and Role-Playing (1984) 34 J Legal Educ 527.

LC Anderson and CE Kirkwood, Teaching Civil Procedure with the Aid of Local Tort Litigation (1987) 37 J Legal Educ 215; Brest, supra note 5; Burg, supra note 33 at 251; Brown, supra note 5 at 1-14.

AV Alfieri, Essay: The Politics of Clinical Knowledge (1990) 35 NY Law Sch L Rev 7; DR Barnhizer, The University Ideal and Clinical Legal Education (1990) 35 NY Law Sch L Rev 87; Condlin, supra note 28; L Grosberg, Introduction: Colloquium: Currents in Clinical Scholarship (1990) 35 NY Law Sch L Rev 1; Spiegel, supra note 25; M Tushnet, Scenes from the Metropolitan Underground: A Critical Perspective on the Status of Clinical Legal Education (1984) 52 Geo Wash L Rev 272.

5 Anderson \& Catz, supra note 56; JM Brown, Simulation Teaching; A TwentySecond Semester Report (1984) 34 J Legal Educ 638; Brest, supra note 5; Bird, supra note 51 at 359; Miller, Learning Professional Responsibility - Clinical Approach in CLE for the Law Student; Papers for the CLEPR National Conference June 69,1973 (CLEPR, 1973) at 99; Ogden, supra note 16.

Spiegelman, supra note 22; K Kreiling, Clinical Education and Lawyer Competency: The Process of Learning to Learn from Experience Through Properly Structured Clinical Supervision (1981) 40 Md L Rev 284; Bellow, supra note 10; Vetri, supra note 70 at 206-7; SD Pepe, Clinical Legal Education: Is Taking Rites Seriously a Fantasy, Folly or Failure? (1985) $18 U$ Mich J L Ref 307; NW Tarr, Skill of Evaluation as an Explicit Goal of Clinical Training (1990) 21 Pac LJ 967.

D Weisbrot, Australian Lawyers (Melbourne: Longman Professional, 1990) Chapter 5 at 131-135 citing the Pearce Report.

M Le Brun, Reflections on Legal Studies Courses in Australian Secondary Schools: Instrumental or Liberal education? (1990) 12 Adel L Rev 389 at 408; C Sampford, Rethinking the Core Curriculum (1989) 12 Adel L Rev 38; C Sampford \& D Wood, 'Theoretical Dimensions' of Legal Education - a Response to the Pearce Report (1988) 62 ALJ 32 at 36-37; Weisbrot, id Chapter 5 at 131-135 citing the Pearce Report; M Chesterman \& D Weisbrot, Legal Scholarship in Australia (1987) 50 Mod L Rev 709.

Brown, supra note 75 at 638 .

Vetri, supra note 70 at 211; RAB Bush, Using Process Observation to Teach Alternative Dispute Resolution: Alternatives to Simulation (1987) $37 \mathrm{~J} \mathrm{Legal}$ Educ 46.

School of Law, Boalt Hall, University of California, Berkeley 1990-91 Announcements, 9; HL Packer, T Ehrlich and S Pepper, New Directions in Legal Education (New York: McGraw-Hill, 1972).

Spiegelman, supra note 22.

SH Leleiko, Clinical Education, Empirical Study and Legal Scholarship (1979)

$30 \mathrm{~J}$ Legal Educ 149; Chay, supra note 1 at 52; Condlin, supra note 28; Tushnet, supra note 74.

Menkel-Meadow, supra note 29 at 571.

Menkel-Meadow id at 572; R Bird, Symposium: Prefatory Remarks (1980) 29 Clev St L Rev 356. 
J Leg Educ 344 at 345 and 350; S Wizner and D Curtis, 'Here's What We Do': Some Notes About Clinical Legal Education (1980) 29 Clev St L Rev 673 at 678; FS Bloch, The Andragogical Basis of Clinical Legal Education (1982) 35 Vand L Rev 321; P Goldfarb, A Theory-Practice Spiral: The Ethics of Feminism and Clinical Legal Education (1991) 75 Minn L Rev 1599; Symposium, Theoretics of Practice: The Integration of Progressive Thought and Action (1992) 43 Hastings LJ (No. 4).

C Menkel-Meadow, The Legacy of Clinical Education: Theories About Lawyering (1980) 29 Clev St L Rev 555.

88 Perhaps the leading proponents of the two main schools are D Binder, P Bergman and S Price, Lawyers as Counselors: A Client-Centered Approach (1990) 35 NY Law Sch L Rev 29, and W Simon, Homo Psychologicus: Notes on a New Legal Formalism (1980) 32 Stan L Rev 487.

D Weisbrot, Recent Statistical Trends in Australian Legal Education (1990-91) 2 Legal Educ Rev 219 at 228. Pearce, supra note 45 at 25.

Compson, Objectives of Legal Education: An Alternative Approach (1978) 52 ALJ 83 at 90; C Menkel-Meadow, Can a Law Teacher Avoid Teaching Legal Ethics? (1991) 41 J Legal Educ 3.

Id Menkel-Meadow; H Lesnick, Infinity in a Grain of Sand: The World of Law and Lawyering as Portrayed in the Clinical Teaching Implicit in the Law School Curriculum (1990) 3 UCLA L Rev 1157.

93 DR Barnhizer, The Clinical Method of Legal Instruction: Its Theory and Implementation (1979) 30 J Legal Educ 67; Kayne, Cases Illustrating Ethical Problems in CLE for the Law Student; Papers for the CLEPR National Conference June 6-9, 1973 (CLEPR, 1973) at 114; Miller, Learning Professional Responsibility-Clinical Approach in CLE for the Law Student; Papers for the CLEPR National Conference June 6-9, 1973 (CLEPR, 1973) at 99; Pincus, supra note 65; Pearce, supra note 45, Vol 1, at 123-4. See also sources in footnote 28. There is not universal agreement on this point. See C Condlin, Clinical Education in the Seventies: An Appraisal of the Decade (1983) 33 J Legal Educ 604 and replies immediately following.

94 Bloch, supra note 49 at 322, note 4; Brest, supra note 56; JM Brown, Simulation Teaching; A Twenty-Second Semester Report (1984) 34 J Legal Educ 638; Burg, supra note 33 at 251; LC Anderson \& CE Kirkwood, Teaching Civil Procedure with the Aid of Local Tort Litigation (1987) 37 J Legal Educ 215; Cranston, supra note 4 at 63.

95 Pearce, supra note 45, Vol 1 at 123; Pincus, supra note 65.

96 Pearce Report supra note 45, Pincus, supra note 65; Miller, supra note 75 at 99; Bloch, supra note 49.

97 Amsterdam, supra note 13.

98 Spiegelman, supra note 22; K Kreiling, Clinical Education and Lawyer Competency: The Process of Learning to Learn from Experience Through Properly Structured Clinical Supervision (1981) 40 Md L Rev 284; Bellow, supra note 10 ; Vetri, supra note 70 at 206-7; Pepe, supra note 76.

99 Spiegelman, supra note 22, at 257.

100 Amsterdam, supra note 13 at 617.

101 Anderson \& Catz, supra note 28 at 738.

102 Stewart, supra note 1 at 473; Sampford \& Wood, supra note 78.

103 RA Gorman, "Educating Lawyers: Tensions and Opportunities" AALS Newsletter 4 Nov 1991, citing the Cramton Report. Brackets and emphasis in original.

104 P Bergman, A Sherr \& R Burridge, Learning from Experience: Non-legally Specific Roleplays (1987) 37 J Legal Educ 535 at 537, citing DA Kolb and R 
Fry, Toward an Applied Theory of Experiential Learning in Theories of Group Processes, (New York: 1975) at 33.

105 Id Bergman at 538.

106 Id at 537; K Kreiling, Clinical Education and Lawyer Competency: The Process of Learning to Learn from Experience Through Properly Structured Clinical Supervision (1981) $40 M d L \operatorname{Rev} 284$ at 286.

107 Spiegelman, supra note 22, at 257.

108 Harbaugh, supra note 17 at 191 and 208.

109 Id at 209.

110 Id at 209.

111 R Barnhizer, The Clinical Method of Legal Instruction: Its Theory and Implementation (1979) $30 \mathrm{~J}$ Legal Educ 67; Tushnet, supra note 74; Bird, supra note 51 at 359 .

112 Stewart, supra note 1 at 475.

113 Id at 476-7.

114 G Bellow, On Talking Tough to Each Other: Comments on Condlin (1983) $33 \mathrm{~J}$ Legal Educ 619; C Condlin, Clinical Education in the Seventies: An Appraisal of the Decade (1983) 33 J Legal Educ 604.

115 Amsterdam, supra note 13 at 617-8; AALS/ABA Report of the Committee on Guidelines for Clinical Legal Education at 11; E Burg, Clinic in the Classroom: A Step Toward Cooperation (1987) 37 J Legal Educ 232; HL Packer, T Ehrlich \& S Pepper, New Directions in Legal Education (New York: McGraw-Hill, 1972); Pepe, supra note 76.

116 Ogden, supra note 16 at 664.

117 Pepe, supra note 76 at 333-337; Condlin, supra note 28 at 59-60.

118 Nash, supra note 65 at 539.

119 Pepe, supra note 76 at 335-336.

120 Bird, supra note 51 at 358 .

121 Bellow, supra note 114; Brest, supra note 5; Brown, supra note 75; N Redlich, Professional Responsibility of a Law Teacher (1980) 29 Clev St L Rev 623.

122 Pepe, supra note 76 at 335-336.

123 AALS, AALS CLE Panel: Evaluation and Assessment of Student Performance in a Clinical Setting (1980) 29 Clev St L Rev 603; Stewart, supra note 1 at 4767.

124 Bellow, supra note 10 at 386; P Bergman, A Sherr and R Burridge, Learning from Experience: Nonlegally Specific Roleplays (1987) 37 J Legal Educ 535 at 536-8.

125 Pincus, supra note 65.

126 DR Barnhizer, The Clinical Method of Legal Instruction: Its Theory and Implementation (1979) $30 \mathrm{~J}$ Legal Educ 67 at 71.

127 Spiegelman, supra note 22.

128 M Galanter, supra note 30.

129 H Astor and C Chinkin, Teaching Dispute Resolution: A Reflection and Analysis (1990) 2 Legal Ed Rev 1; PG Schrag and J White, A Two-Front Negotiation Exercise (1986) 88 W Va L Rev 729; LL Riskin and JE Westbrook, Integrating Dispute Resolution into Standard First-Year Courses; the Missouri Plan (1989) 39 J Legal Educ 509; Galanter, supra note 10; DR Moore and J Tomlinson, The Use of Simulated Negotiation to Teach Substantive Law (1969) $21 \mathrm{~J}$ Legal Educ 579; J Weinstein, Teaching Mediation in Law Schools: Training Lawyers to Be Wise (1990) 35 NY Law Sch L Rev 199.

130 Spiegelman, supra note 22 at 258-9. Footnotes omitted.

131 Id at 258-9. 
132 McAninch, supra note 23 at 426. 